\title{
Description of a new species of Pareiorhaphis (Loricariidae: Neoplecostominae) from the rio Jequitinhonha basin, Minas Gerais, eastern Brazil
}

\author{
Edson H. L. Pereira ${ }^{1}$, Tiago C. Pessali ${ }^{2}$, Francisco de Andrade ${ }^{3}$ and Roberto E. Reis ${ }^{1}$
}

\begin{abstract}
A new species of the loricariid genus Pareiorhaphis is described based on specimens from several tributaries of the upper and middle rio Jequitinhonha basin, Minas Gerais State, eastern Brazil. The new species increases the number of known species of Pareiorhaphis to 25 and, at the same time, represents the second member of the subfamily Neoplecostominae reported from the rio Jequitinhonha basin. The new species is diagnosed from all remaining congeners by a putative autapomorphic feature related to the color pattern: a well-defined, dark brown stripe on the median series of lateral plates that extends along the flank from the posterior margin of compound pterotic to the caudal-fin base. The shallow caudal peduncle and the comparatively larger number of dentary teeth also distinguish the new species from most congeners. The new species is also compared to Pareiorhaphis stephanus, a syntopic congener with similar traits.
\end{abstract}

Keywords: Cascudos, Coastal drainages, Endemism, Itacambiruçu River, Taxonomy.

Uma nova espécie de loricariídeo do gênero Pareiorhaphis é descrita com base em espécimes coletados em vários tributários da parte superior e média da bacia do rio Jequitinhonha, no estado de Minas Gerais, leste do Brasil. A nova espécie eleva para 25 o número de espécies conhecidas de Pareiorhaphis e ao mesmo tempo representa o segundo registro de um membro de Neoplecostominae na bacia do rio Jequitinhonha. A nova espécie é diagnosticada de todas as demais congêneres por uma característica até então única relacionada ao padrão de colorido, uma faixa marrom escura bem definida na série média de placas laterais, que se estende ao longo do flanco, desde a margem posterior do pterótico composto até a base dos raios médios da nadadeira caudal. O pedúnculo caudal baixo e o número de dentes comparativamente alto no dentário, também distinguem a nova espécie da maioria das demais congêneres. A nova espécie é comparada com Pareiorhaphis stephanus, uma congênere sintópica com caracteres similares.

Palavras-chave: Bacias costeiras, Cascudos, Endemismo, Rio Itacambiruçu, Taxonomia.

\section{Introduction}

Pareiorhaphis Miranda Ribeiro comprises a distinctive assemblage of loricariid catfishes with 25 known species, including the new taxon described in this report. Species of this genus exhibit a significant variation in body size, color pattern, nature of the pectoral girdle covering, shape of the head, and other morphometric and meristic traits. However, a common pattern related to the sexually dimorphic attributes associated with adult males is shared by all species of the genus and diagnoses Pareiorhaphis among all other neoplecostomines, namely the hypertrophied odontodes that cover most of the cheek, opercle, and exposed lateral process of the cleithrum (Pereira et al., 2007, 2010). The type locality of the new species is located in the rio Itacambiruçu, one of the main tributaries of the rio Jequitinhonha, a coastal drainage included in the Northeastern Mata Atlântica freshwater ecoregion (Abell et al., 2008), which harbors high levels of fish endemism (Camelier, Zanata, 2014). In addition, no other neoplecostomine have been reported in that basin since Oliveira, Oyakawa (1999) described Pareiorhaphis stephanus from the ribeirão das Pedras, a headwater tributary to the rio Jequitinhonha basin near Diamantina,

${ }^{1}$ Pontifícia Universidade Católica do Rio Grande do Sul (PUCRS), Laboratório de Sistemática de Vertebrados, Av. Ipiranga 6681, 90619-900 Porto Alegre, RS, Brazil. (EHLP) ehlpereira@gmail.com, (RER) reis@pucrs.br

${ }^{2}$ Museu de Ciências Naturais, Pontifícia Universidade Católica de Minas Gerais, Av. Dom José Gaspar 290, 30535-610 Belo Horizonte, MG, Brazil.tcpessali@hotmail.com

${ }^{3}$ Pós Graduação em Ecologia Aplicada, Departamento de Biologia, Setor de Ecologia, Universidade Federal de Lavras, Caixa Postal 3037 , 37200-000 Lavras, MG, Brazil.surubim@gmail.com 
Minas Gerais State. Recently, however, a possible second species of Pareiorhaphis has been identified based on DNA barcode comparison and since its genetic distance from P. stephanus was higher than $2 \%$ (namely $5.79 \%$ ), it was considered a candidate new species by Pugedo et al. (2016), what was confirmed with the present morphometric analysis. Various ichthyological surveys conducted by the authors in tributaries to upper and middle portions of the rio Jequitinhonha basin during the last few years, have produced good series of that distinct, undescribed species of Pareiorhaphis, which is formally described in the present paper.

\section{Material and Methods}

Specimens examined belong to the American Museum of Natural History, New York (AMNH); Academy of Natural Sciences of Drexel University, Philadelphia (ANSP); Auburn University Museum, Auburn (AUM); Laboratório de Ictiologia de Ribeirão Preto, Universidade de São Paulo, Ribeirão Preto (LIRP); Museu de Ciências Naturais, Pontifícia Universidade Católica de Minas Gerais, Belo Horizonte (MCNIP); Museu de Ciências e Tecnologia, Pontifícia Universidade Católica do Rio Grande do Sul, Porto Alegre (MCP); Museu Nacional, Rio de Janeiro (MNRJ); and Museu de Zoologia da Universidade Estadual de Londrina, Londrina (MZUEL). Comparative material of Pareiorhaphis species is listed in Pereira et al. (2012), with the addition of Pareiorhaphis lophia in Pereira, Zanata (2014), P. proskynita in Pereira, Britto (2012), P. garapia in Pereira et al. (2015), $P$. vetula in Pereira et al. (2016), and P. stephanus below. The subfamily Neoplecostominae is used herein in the sense of Pereira, Reis (2017). Counts and measurements were taken according to Pereira et al. (2007). Counts of procurrent caudal-fin rays and vertebrae were made in two cleared and counterstained specimens (c\&s) prepared according to Taylor, Van Dyke (1985). Vertebral counts include five centra in the Weberian Apparatus and the fused ural + preural centra, which was counted as one element. Nomenclature and counts for body plates follow Schaefer (1997). Morphometric features were obtained with digital calipers to the nearest $0.1 \mathrm{~mm}$ and were made from point to point under a stereomicroscope. Standard length (SL) is expressed in millimeters while all other measurements are given as percent of standard length or head length (HL). In the list of examined material, museum abbreviation and catalog number come first, followed by the number and SL range of specimens in that lot, the number and SL range of specimens measured for the morphometric comparisons, in parentheses, and locality. Conservation status of the new species was evaluated according the categories and criteria of the International Union for Conservation of Nature (IUCN, 2016). The Extent of Occurrence (EOO) was calculated by the minimum convex polygon method, using the software Google Earth Pro.

\section{Results}

\section{Pareiorhaphis lineata, new species}

urn:1sid:zoobank.org:act:41768249-5E1B-44AA-AECAAD68E44EBEE7

Fig. 1, Tab. 1

Holotype. MCP 50863, $95.1 \mathrm{~mm}$ SL, male, Brazil, Minas Gerais State, Grão Mogol, rio Jequitinhonha basin, rio Itacambiruçu, 16³5'51.6”'S 4250'15.4”W, 23 Nov 2010, F. Andrade \& W. A. Santos.

Paratypes. Brazil: Minas Gerais State: rio Jequitinhonha drainage: AMNH 266888, 3, 63.1-72.3 mm SL; AUM 67843, 3, 65.6-73.4 mm SL; MCP 50880, 27, 25.1-64.1 mm SL, Josenópolis, ribeirão Piabanha, left margin tributary to rio Jequitinhonha, $16^{\circ} 32^{\prime} 46.08^{\prime \prime S} 42^{\circ} 311^{\prime} 42.18^{\prime \prime} \mathrm{W}, 13$ Apr 2015, T. C. Pessali, G. M. Santos \& I. S. Penido. MCNIP 1494, 2, 68.1-74.6 mm SL (1, 74.6 mm SL), Grão Mogol, rio Itacambiruçu, $16^{\circ} 35^{\prime} 16.37^{\prime}$ 'S 42 $48^{\prime} 53.19^{\prime \prime} \mathrm{W}$, 6 Apr 2013, T. C. Pessali, M. L. Pugedo, A. A. Rodrigues \& G. N. Salvador. MCNIP 1495 (1, 74.0 mm SL), Grão Mogol, rio Itacambiruçu, $16^{\circ} 35^{\prime} 12.45^{\prime}$ 'S $42^{\circ} 51$ '15.82”W, 10 Apr 2013, T. C. Pessali, M. L. Pugedo, A. A. Rodrigues \& G. N. Salvador. MCNIP 1499, 7, 30.8-71.7 mm SL (2, 68.8-71.7 mm SL), Cristália, rio Itacambiruçu at Praia do Vau, 16³5'25.89”S 4253'23.98”W, 19 Sep 2012, T. C. Pessali \& G. C. G. Mello. MCNIP 1701 (2, 87.0$93.2 \mathrm{~mm}$ SL), Itaobim, ribeirão São João, 16³9'30.29”S 41 30’04.91'W, 12 Sep 2015, T. C. Pessali, T. A. Barroso \& S. G. Máximo. MCNIP 1703, 8, 34.3-84.4 mm SL (1, 84.4 mm SL), Grão Mogol, rio Itacambiruçu, $16^{\circ} 35^{\prime} 16.37^{\prime} \mathrm{S}$ 4248'53.19”W, 29 Dec 2014, T. C. Pessali, J. C. de Oliveira \& I. S. Penido. MCNIP 1708, 8, 50.0-87.8 mm SL, Grão Mogol, rio Itacambiruçu, $16^{\circ} 35^{\prime} 12.45^{\prime} \mathrm{S}$ 42 $51^{\circ} 15.82^{\prime \prime} \mathrm{W}, 15$ Sep 2014, T. C. Pessali, A. A. Rodrigues \& D. F. Teixeira. MCNIP 1729, 18, 39.1-82.0 mm SL (3, 79.4-82.0 mm SL), Ponto dos Volantes, ribeirão São Joanico, left margin tributary to ribeirão São João, $16^{\circ} 52$ '52.81'’S 41 ${ }^{\circ} 29^{\prime} 22.42^{\prime \prime} \mathrm{W}, 17 \mathrm{Apr}$ 2015, T. C. Pessali, G. M. Santos \& I. S. Penido. MCNIP 1725, 2, 72.9-115.7 mm SL (1, $115.7 \mathrm{~mm} \mathrm{SL})$, Ponto dos Volantes, ribeirão São João, right margin tributary to rio Jequitinhonha, $16^{\circ} 58^{\prime} 47.91^{\prime \prime S} 41^{\circ} 26^{\prime} 51.20^{\prime \prime} \mathrm{W}, 17$ Apr 2015, T. C. Pessali, G. M. Santos \& I. S. Penido. MCP 50862, 2, 88.9-91.9 mm SL (1, 91.9 mm SL), Grão Mogol, rio Itacambiruçu, $16^{\circ} 35^{\prime} 51.06$ ”S 4250'15.04”W, 19 May 2010, F. Andrade \& W. A. Santos. MCP 50876, 9, 58.3-90.0 mm SL (7, 58.3-90.0 mm SL), Grão Mogol, rio Itacambiruçu, $16^{\circ} 35^{\prime} 12^{\prime \prime} \mathrm{S} 42^{\circ} 51^{\prime} 15^{\prime \prime} \mathrm{W}, 30 \mathrm{Dec} 2011$, T. C. Pessali \& A. A. Rodrigues. MCP 50879 (2, 87.5$96.9 \mathrm{~mm}$ SL), Cristália, rio Itacambiruçu, 16³6'23.96”'S $42^{\circ} 49^{\prime} 46.83^{\prime}$ 'W, 10 Feb 2014, T. C. Pessali, N. G. Sales \& G. M. Santos. MCP 50881, 6, 41.9-95.7 mm SL (3, 66.4-95.7 
mm SL), Grão Mogol, rio Itacambiruçu, 16³5'12.45"S 42 51'15.82”W, 16 Sep 2012, T. C. Pessali \& G. C. G. Mello. MCP 50882, 9, 38.7-94.6 mm SL (2, 75.3-94.6 $\mathrm{mm}$ SL), Grão Mogol, rio Itacambiruçu, $16^{\circ} 35^{\prime} 12.45^{\prime} \mathrm{S}$ 42 51'15.82'W, 27 Dec 2014, T. C. Pessali, J. C. de Oliveira \& I. S. Penido. MCP 44927, 5, 40.5-84.3 mm SL (2, 71.6-84.3 mm SL); MNRJ 48689, 3, 66.5-73.5 mm SL
(2, 66.5-73.5 mm SL), Leme do Prado, ribeirão Correntes at Mandaçaia, 16 $59^{\circ} 47^{\prime \prime S} 42^{\circ} 44^{\prime} 43^{\prime \prime W}, 21$ Jan 2010, R. E. Reis, P. Lehmann \& E. H. L. Pereira. MZUEL 17319, 2, 71.7-87.9 mm SL; and MCP 50971, 6, 60.9-98.4 mm SL + 2 c\&s, 78.5-88.0 mm SL, Grão Mogol, rio Itacambiruçu, $16^{\circ} 35^{\prime} 51.4^{\prime \prime S} 42^{\circ} 50^{\prime} 15.4^{\prime \prime} \mathrm{W}, 4$ Jun 2011, F. Andrade, L. Durães, A. Santos \& H. J. Alves.

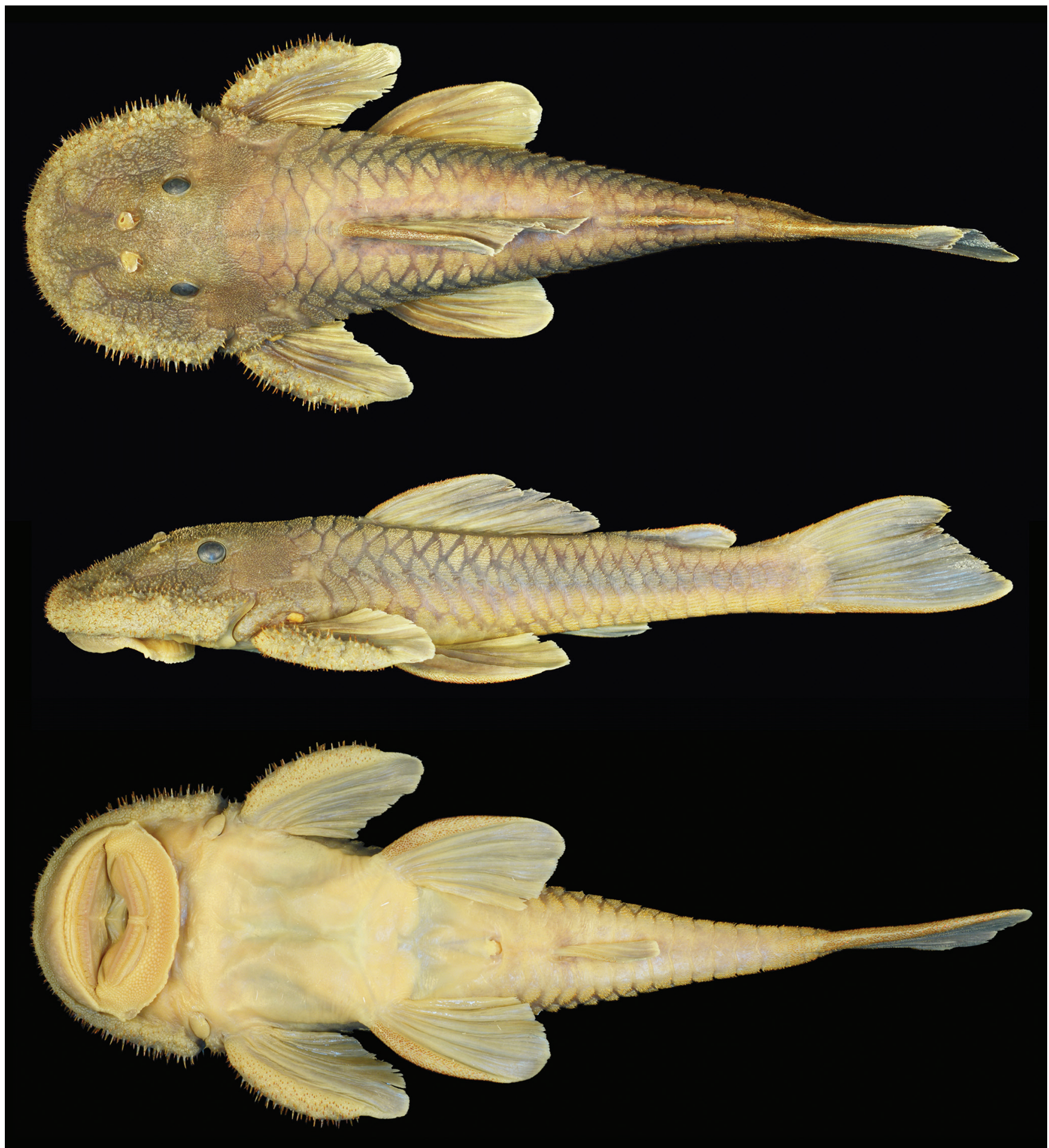

Fig. 1. Pareiorhaphis lineata, MCP 50863, holotype, 95.1 mm SL, Brazil, Minas Gerais State, Grão Mogol, rio Jequitinhonha basin, rio Itacambiruçu. 
Tab. 1. Morphometric and meristic data of Pareiorhaphis lineata. Values are given as percents of standard length or head length. $\mathrm{H}=$ holotype, $\mathrm{n}=$ number of specimens, and $\mathrm{SD}=$ standard deviation.

\begin{tabular}{|c|c|c|c|c|c|c|}
\hline & $\mathrm{H}$ & $\mathrm{n}$ & Low & High & Mean & SD \\
\hline Standard length (mm) & 95.1 & 31 & 58.3 & 115.7 & 81.0 & - \\
\hline \multicolumn{7}{|c|}{ Percent of standard length } \\
\hline Head length & 33.5 & 31 & 31.3 & 35.7 & 34.1 & 0.94 \\
\hline Predorsal length & 42.8 & 31 & 40.4 & 44.0 & 42.4 & 0.98 \\
\hline Postdorsal length & 38.8 & 31 & 36.1 & 41.5 & 38.9 & 1.32 \\
\hline Preanal length & 66.6 & 31 & 63.5 & 68.9 & 65.4 & 1.16 \\
\hline Preadipose length & 82.2 & 31 & 78.5 & 82.8 & 80.1 & 1.12 \\
\hline Dorsal-fin spine length & 19.4 & 31 & 18.1 & 23.0 & 19.9 & 1.12 \\
\hline Anal-fin unbranched ray length & 9.5 & 31 & 9.4 & 12.9 & 11.0 & 0.83 \\
\hline Pectoral-fin spine length & 19.3 & 31 & 17.4 & 23.9 & 20.5 & 1.42 \\
\hline Pelvic-fin unbranched ray length & 19.8 & 31 & 18.2 & 22.2 & 19.9 & 1.06 \\
\hline Upper caudal-fin ray & 20.1 & 29 & 19.5 & 23.5 & 21.7 & 1.14 \\
\hline Lower caudal-fin ray & 26.0 & 29 & 24.1 & 31.8 & 27.6 & 1.83 \\
\hline Adipose-fin spine length & 9.7 & 30 & 9.4 & 11.6 & 10.3 & 0.63 \\
\hline Adipose to caudal fin distance & 20.0 & 31 & 18.3 & 22.6 & 20.7 & 1.04 \\
\hline Trunk length & 19.9 & 31 & 17.1 & 20.9 & 19.4 & 0.86 \\
\hline Abdominal length & 22.6 & 31 & 20.1 & 22.8 & 21.6 & 0.70 \\
\hline Cleithral width & 31.5 & 31 & 28.5 & 31.5 & 30.0 & 0.88 \\
\hline Body depth at dorsal-fin origin & 18.4 & 31 & 13.3 & 19.9 & 16.9 & 1.44 \\
\hline Body width at dorsal-fin origin & 22.6 & 30 & 20.9 & 25.5 & 22.5 & 1.02 \\
\hline Body width at anal-fin origin & 15.2 & 31 & 12.3 & 15.6 & 14.0 & 0.78 \\
\hline Caudal peduncle length & 36.7 & 31 & 33.8 & 38.8 & 35.6 & 1.10 \\
\hline Caudal peduncle depth & 8.9 & 31 & 7.9 & 9.0 & 8.5 & 0.29 \\
\hline Caudal peduncle width & 5.2 & 31 & 4.2 & 5.5 & 4.8 & 0.32 \\
\hline \multicolumn{7}{|c|}{ Percent of head length } \\
\hline Snout length & 66.4 & 31 & 60.8 & 66.5 & 63.8 & 1.27 \\
\hline Orbital diameter & 13.3 & 31 & 12.7 & 16.2 & 14.2 & 0.76 \\
\hline Interorbital width & 30.2 & 31 & 27.2 & 31.6 & 29.4 & 1.28 \\
\hline Head depth & 51.7 & 31 & 41.3 & 55.6 & 47.7 & 3.16 \\
\hline Mandibular ramus & 26.8 & 31 & 23.6 & 27.8 & 25.8 & 1.10 \\
\hline Meristics & & & & & Mode & \\
\hline Premaxillary teeth left/right & $101 / 102$ & 28 & $65 / 66$ & $101 / 103$ & 80 & 8.31 \\
\hline Dentary teeth left/right & $105 / 103$ & 28 & $69 / 66$ & $105 / 103$ & 83 & 9.07 \\
\hline Plates in median lateral series left/right & $26 / 25$ & 31 & $24 / 24$ & $26 / 27$ & 25 & 0.62 \\
\hline Plates at dorsal-fin base & 7 & 31 & 6 & 7 & 7 & 0.43 \\
\hline Plates between dorsal and adipose & 7 & 31 & 6 & 7 & 6 & 0.49 \\
\hline Plates between adipose and caudal & 3 & 31 & 2 & 4 & 3 & 0.26 \\
\hline Plates at anal-fin base & 3 & 31 & 2 & 4 & 3 & 0.43 \\
\hline Plates between anal and caudal & 12 & 30 & 11 & 12 & 11 & 0.48 \\
\hline Pre-adipose azygous plates & 3 & 31 & 1 & 4 & 2 & 0.75 \\
\hline
\end{tabular}

Non-types. Brazil: Minas Gerais State: rio Jequitinhonha basin: ANSP 174076, 5, 50.4-67.8 mm SL; MCP 18039, 3, 22.4-72.8 mm SL + 1 c\&s 63.9 mm SL, Padre Paraíso, rio São João on road BR-116 between Padre Paraíso and Itaobim, ca. $119 \mathrm{~km}$ of Teófilo Otoni, 1656'06”S 41²7’46”W, 20 Jan 1995, R. E. Reis, W. G. Saul, J. F. P. da Silva \& E. H. L. Pereira. MCNIP 0005, 4, 25.5-62.2 mm SL, Grão Mogol, rio Itacambiruçu, 16³4'52”S 4252’25”W, Sep 2011, T. C. Pessali \& G. R. Rosa. MCNIP 0009, 2, 50.2-63.5 mm SL,

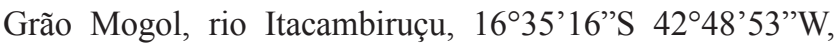
Sep 2011, T. C. Pessali \& G. R. Rosa. MCNIP 1496, 6, 53.9-
65.3 mm SL, Grão Mogol, rio Itacambiruçu, 16 $35^{\prime}$ '12.45”S $42^{\circ} 51$ '15.82"W, 2 Nov 2013, T. C. Pessali \& T. A. Barroso. MCNIP 1498, 4, 40.9-68.3 mm SL, Grão Mogol, rio Itacambiruçu, 16³4'52.79”S 4252'25.73”W, 17 Sep 2012, T. C. Pessali \& G. C. G. Mello. MCNIP 1712, 13, 36.963.5 mm SL, Grão Mogol, rio Itacambiruçu, 16 35'16.37’S $42^{\circ} 48^{\prime} 53.19$ 'W, 16 Sep 2014, T. C. Pessali, A. A. Rodrigues \& D. F. Teixeira. MCNIP 1713, 3, 47.4-56.8 mm SL, Grão Mogol, rio Itacambiruçu at Praia do Vau, 16 35'25.89”S 4253'23.98’W, 18 Sep 2014, T. C. Pessali, A. A. Rodrigues \& D. F. Teixeira. MCNIP 1697, 1, 73.9 mm SL, Grão Mogol, 
rio Itacambiruçu, $16^{\circ} 35^{\prime} 50.35^{\prime} \mathrm{S} 42^{\circ} 50^{\prime} 22.39^{\prime \prime} \mathrm{W}, 31 \mathrm{Dec}$ 2014, T. C. Pessali, J. C. de Oliveira \& I. S. Penido. MCNIP 1719,3 , 35.9-44.1 mm SL, Grão Mogol, rio Itacambiruçu, $16^{\circ} 35^{\prime} 58.02^{\prime \prime S} 42^{\circ} 55^{\prime} 37.42^{\prime \prime W}, 27$ Jul 2013, T. C. Pessali, M. L. Pugedo \& I. S. Penido. MCNIP 1721, 7, 40.1-72.8 mm SL, Grão Mogol, rio Itacambiruçu, 16³5'12.45"S 4251'15.82”W, 10 Apr 2015, T. C. Pessali, G. M. Santos \& I. S. Penido. MCNIP 1722, 5, 38.2-45.1 mm SL, Grão Mogol, rio Itacambiruçu, $16^{\circ} 35^{\prime} 16.37^{\prime \prime S} 42^{\circ} 48^{\prime} 53.19^{\prime \prime} \mathrm{W}, 11$ Apr 2015, T. C. Pessali, G. M. Santos \& I. S. Penido. MCNIP 1724, 5, 34.0-58.7 mm SL, Grão Mogol, rio Itacambiruçu, 16³4'52.79”'S 4252'25.73”W, 23 Jul 2013, T. C. Pessali, M. L. Pugedo \& I. S. Penido. MCNIP 1711, 17, 36.3-77.2 mm SL, Grão Mogol, rio Itacambiruçu, 16³4'52.79”'S $42^{\circ} 52^{\prime} 25.73^{\prime \prime} \mathrm{W}, 14$ Sep 2014, T. C. Pessali, A. A. Rodrigues \& D. F. Teixeira. MCP 36916, 9, 24.6-78.0 mm SL + 1 c\&s 65.9 mm SL (3, 64.6-78.0 mm SL), Itaobim, rio São João on road BR-116 between Padre Paraíso and Itaobim, $c a$.

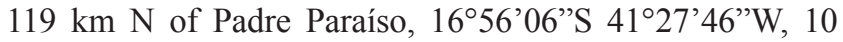
Oct 2004, R. E. Reis, P. Lehmann \& E. H. L. Pereira. MCP 49292, 16, 34.4-74.6 mm SL, Itamarandiba, headwaters of rio Itacambira Grande on road from Itacambira to Senador Modestino Gonçalves, ca. 14 km of Itamarandiba, 1753'23'S 42॰59'57'W, 27 Jul 2015, R. E. Reis, P. Lehmann \& E. H. L. Pereira. MCP 49362, 20, 21.3-52.3 mm SL, Itamarandiba, rio Itanguá, tributary to rio Araçuaí on road from Itamarandiba to Senador Modestino Gonçalves, $c a .30 \mathrm{~km}$ of Itamarandiba, 1754’38'S 4307’07’W, 27 Jul 2015, R. E. Reis, E. H. L. Pereira \& P. Lehmann. MCNIP 1716, 3, 40.1-51.7 mm SL, Bocaiúva, rio Macaúbas, left margin tributary to rio Jequitinhonha, $17^{\circ} 13^{\prime} 13.49^{\prime \prime S} \quad 43^{\circ} 29^{\prime} 21.43^{\prime \prime W}, 6$ Apr 2015, T. C. Pessali, G. M. Santos \& I. S. Penido. MCNIP 1714, 1, 53.9 mm SL, Olhos D'Água, ribeirão dos Ferreira, right margin tributary to ribeirão da Areia, $17^{\circ} 26^{\prime} 09.57^{\prime \prime} \mathrm{S}$ $43^{\circ} 37^{\prime} 02.25^{\prime \prime} \mathrm{W}, 20$ Sep 2014, T. C. Pessali, A. A. Rodrigues \& D. F. Teixeira. MCNIP 1723, 1, 54.8 mm SL, Josenópolis, córrego Curralinho, tributary to ribeirão Piabanha, itself a left margin tributary to rio Jequitinhonha, $16^{\circ} 30^{\prime} 56.73^{\prime \prime} \mathrm{S}$ 42³2'54.82”W, 13 Apr 2015, T. C. Pessali, G. M. Santos \& I. S. Penido. MCP 50861, 1, 59.5 mm SL, Padre Carvalho, rio Vacaria, $16^{\circ} 22^{\prime} 54.07^{\prime}$ 'S $42^{\circ} 28^{\prime} 37.00^{\prime \prime} \mathrm{W}, 1$ Sep 2010, F. Andrade \& W. A. Santos. MCP 50877, 2, 72.8-73.1 mm SL, Grão Mogol, rio Itacambiruçu, $16^{\circ} 35^{\prime} 51^{\prime \prime}$ S 42 $50^{\prime} 06^{\prime} \mathrm{W}$, Nov 2011, F. R. A. Neto, L. D. S. Durães \& T. C. Pessali. MCP 50878, 1, $70.6 \mathrm{~mm} \mathrm{SL}$, Ponto dos Volantes, ribeirão São João, 1645’38.30”S 41²9'29.63”'W, 11 Sep 2015, T. C. Pessali, T. A. Barroso \& S. G. Máximo. MZUEL 12160, 8, 39.3-72.4 mm SL, Setubinha, creek tributary to rio Araçuaí,

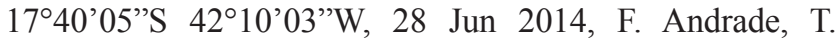
Barroso \& I. G. Prado.

Diagnosis. Pareiorhaphis lineata can be diagnosed from all congeners by a putative autapomorphy, the possession of a dark brown stripe on the median series of lateral plates that extends along the flank from the posterior margin of compound pterotic to the caudal-fin base ( $v s$. no dark stripe on flank). In addition, $P$. lineata can be distinguished from all other congeners, except $P$. stephanus, by having the entire margin of the head ornamented with hypertrophied odontodes in adult males (vs. hypertrophied odontodes on the cheeks only). From the remaining species, except $P$. garbei and P. stephanus, it is distinguished by a longer dorsal fin, whose posterior margin reaches the middle or distinctly beyond the middle of the anal fin when adpressed in adult males ( $v s$. a short dorsal fin, whose posterior margin does not reach to or slightly surpasses the anal-fin origin). The shallower caudal peduncle (7.9-9.0 vs. 9.1-14.0\% SL) also distinguishes $P$. lineata from $P$. azygolechis, $P$. bahianus, $P$. cameroni, P. cerosus, $P$. eurycephalus, $P$. garapia, P. hypselurus, P. lophia, P. mutuca, P. nudulus, $P$. regani, and $P$. stomias. The larger number of dentary teeth (66-105 vs. 30-62) distinguishes Pareiorhaphis lineata from $P$. hystrix, P. parmula, $P$. steindachneri and $P$. vestigipinnis. The new species is further distinguished from $P$. garbei and $P$. stephanus by the pectoral-fin spine, which is ornamented with hypertrophied odontodes shorter than one orbital diameter in adult males ( $v s$. larger hypertrophied odontodes longer than one orbital diameter). The new species is further diagnosed from P. stephanus by having the greatest body width at posterior portion of cheek ( $v s$. greatest body width at cleithrum) and, especially juveniles and females, by the smaller eye diameter $(12.7-16.2 \% \mathrm{HL})$ vs. larger eye diameter (18.1-20.1\% HL); and longer snout (60.8-66.5\% HL) $v s$. shorter snout $(55.5-60.8 \% \mathrm{HL})$.

Description. Counts and proportional measurements in Tab. 1. Overall view of body in Fig. 1. Small to mediumsized loricariid with standard length of measured specimens 58.3-115.7 mm SL. Body elongate and dorsoventrally flattened. Greatest body width at posterior portion of cheek, progressively tapering to end of caudal peduncle. Dorsal profile of body gently convex from snout tip to dorsal-fin origin and almost straight from that point to end of adipose fin, then slightly concave to caudal fin. Greatest body depth immediately anterior to dorsal-fin origin. Least body depth at shallowest part of caudal peduncle. Trunk horizontally oval in cross-section, flattened ventrally; caudal peduncle strongly flattened ventrally and markedly compressed caudally. Lateral-line canal in median plate series uninterrupted, with pored tube from compound pterotic to penultimate plate before caudal fin. Ventral profile almost straight between snout tip and pelvic girdle, then slightly ascending to caudal-fin origin. Dorsolateral surface of body covered by plates except for narrow naked area around dorsal-fin base and opening of swimbladder capsule, posteroventrally to compound pterotic. Predorsal plates arranged in two or three pairs of plates in some specimens, sometimes randomly distributed. Five rows of lateral dermal plates covering body, not forming keels except for ventral series of adult males. Mid-dorsal and midventral series of lateral plates incomplete, ending 5-7 plates before caudal-fin base. Ventral surface of head, abdomen, and region around urogenital opening naked. 
Head broad and moderately depressed, rounded in dorsal view; widened in adult males. Interorbital space flat to slightly concave. Three weak elevations between orbits and snout tip; one median from snout tip to area between nostrils and two in front of orbits. Elevations ornamented with many short hypertrophied odontodes directed upward in adult males. Snout tip with small ovoid area of naked skin; covered by short hypertrophied odontodes in fully developed adult males. Adult males with well-developed soft fleshy lobes extending along lateral and sometimes anterior portions of head. Eye small, dorsolaterally placed; iris operculum small or unnoticeable. Nares ovoid, slightly longer than wide, positioned much closer to anterior margin of orbit than to snout tip. Narrow area of naked skin in front of nostril, between mesial margin of infraorbitals 1 and 2 and prenasal plates. Oral disk oval; lips well developed, occupying most of ventral surface of head. Lower lip wide and long, not reaching pectoral girdle, upper lip narrow. Lower lip densely covered by minute papillae. Papillae surrounded by small naked areas, decreasing in size towards edge and absent near lip margin. Margin of lower lip slightly fringed. Maxillary barbel short, mostly adnate to lower lip and with small free portion distally. Teeth series in both premaxilla and dentary forming shallow arc with overall angle of approximately 130-140 degrees, with mesial ends slightly curved inwards. Teeth slender, asymmetrically bifid, medial cusp slightly curved inwards. Lateral cusp small and pointed, never reaching half-length of medial cusp in unworn teeth.

Dorsal-fin posterior margin straight to slightly concave; usually not contacting preadipose azygous plates when adpressed, sometimes contacting first preadipose plates in adult males. Nuchal plate exposed, not covered by skin. Dorsal-fin spinelet oval-shaped, varying from slightly wider than base to usually narrower than base of dorsal-fin spine, sometimes divided into two small platelets, or absent. Dorsal-fin locking mechanism non-functional. Dorsal-fin spine moderately flexible, followed by seven branched rays. Adipose fin with well-ossified leading spine bearing odontodes. Adipose-fin membrane short or extended slightly beyond adipose-fin spine. Adipose fin preceded by 1-5 (usually 2-3) median preadipose azygous plates. Pectoral-fin origin situated slightly dorsal to pelvic-fin origin. Pectoral fin moderate in size, with spine slightly curved and flattened, covered by minute odontodes in females, immature males, and juveniles. Adult males with pectoral-fin spine very broad, bearing straight and short hypertrophied odontodes over entire outer surface. Pectoral fin with six branched rays, first and second longer than spine. Subsequent branched rays decrease gradually in size, last ray half length of first one. Distal margin of pectoral fin approximately straight. Tip of adpressed pectoral fin almost reaching or reaching to mid-length of pelvic-fin unbranched ray. Pelvic fin with one unbranched and five branched rays, not reaching or just reaching to origin of anal fin when adpressed. Pelvic-fin unbranched ray depressed, covered with minute odontodes ventrally and laterally. Dermal flap on its dorsal surface present and well developed, extending to ray tip in adult males; absent in females. Anal fin short with one unbranched and five branched rays; passing vertical at adiposefin origin when adpressed. Caudal fin with 14 branched rays, posterior margin slightly forked; ventral lobe distinctly longer than dorsal (24.1-31.8 vs.19.5-23.5\% SL). Dorsal caudal-fin lobe with 4-5 and ventral lobe with 3-5 plate-like procurrent rays, posteriormost elongate. Odontodes on principal and procurrent rays small and irregularly arranged. Hypural plate asymmetrical with ventral lobe longer than dorsal. Total vertebral centra 29.

Color in alcohol. Overall background color of dorsal and lateral surface of head and trunk pale yellow to light brown, sometimes brownish gray. Flank with conspicuous dark brown stripe from compound pterotic to caudal fin on median series of lateral plates, distinctly contrasting with lighter color of mid-ventral and ventral series of plates (Fig. 1). Scattered dark blotches and dark saddles common to other species, absent in P. lineata. Ventral surface of head and abdomen yellowish or whitish pale or with small dark grey spots scattered on lateral portion of abdomen and caudal peduncle. Dorsal fin with 3-4 inconspicuous dark blotches on spine and branched rays; interradial membrane darkened. Paired fins darkened anteriorly and pale yellow posteriorly. Caudal fin with rays and interradial membrane gray.

Color in life. Similar to color in alcohol but contrast between dark brown longitudinal stripe and lighter mid-ventral and ventral series of plates more conspicuous. Lateral portion of snout between eye and fleshy lobe on cheek darkened. Distal margin of caudal fin chestnut brown (Fig. 2).

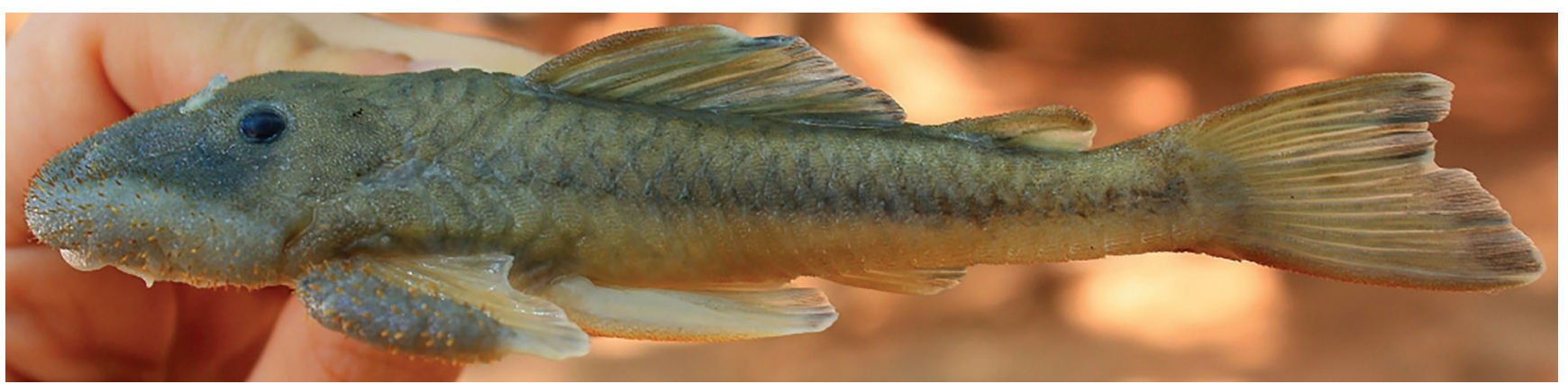

Fig. 2. Pareiorhaphis lineata, MCP 50879, $96.9 \mathrm{~mm}$ SL, paratype photographed right after preservation. Brazil, Minas Gerais State, Cristália, rio Itacambiruçu. 
Sexual dimorphism. Pareiorhaphis lineata shares with all members of the genus the remarkable morphological modifications already known to occur in adult males of Pareiorhaphis. Some of those attributes in the new species are especially developed, as the fleshy lobes that extend along the entire margin of the head and that are ornamented with short emerging hypertrophied odontodes, both of which are absent in females; by a thickened pectoral-fin spine strongly intumescent along its entire length with dorsal, lateral, and ventral surfaces ornamented with short hypertrophied odontodes, sometimes equal in size to those on head margin, that are absent in females; and by the skin fold on the dorsal surface of the unbranched pelvic-fin ray that extends to the ray tip and is slightly higher near the fin base, whereas the skin fold is absent or very reduced in females. Other examples of secondary sexual dimorphism of adult males include distinct keels of the ventral series of lateral plates; three weak elevations between the orbits and the snout tip that are covered with many short hypertrophied odontodes directed upward; dorsal-fin posterior margin that sometimes contacts the first preadipose plate; and possession of a much broader head than females. Compared to males, females possess an enlarged, swollen urogenital opening, while males have small and pointed urogenital papillae.

Geographical distribution. Upper and middle rio Jequitinhonha basin in the state of Minas Gerais, Brazil (Fig. 3).

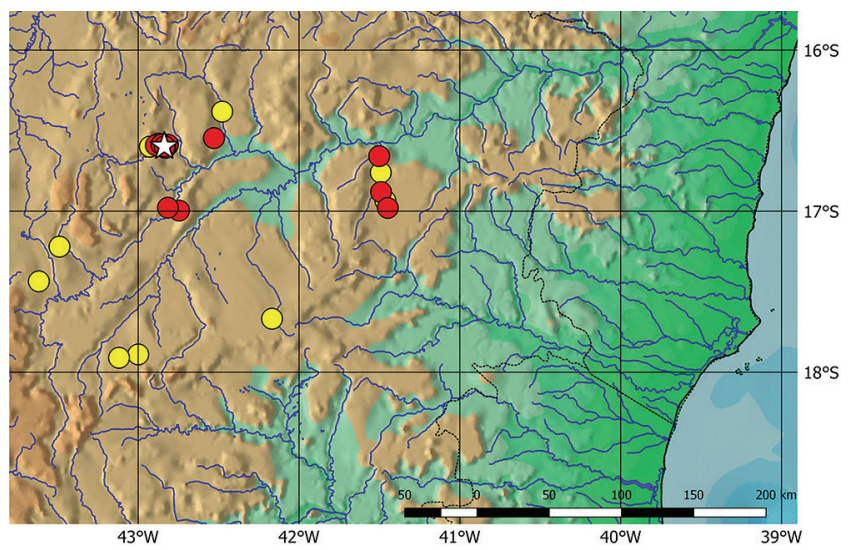

Fig. 3. Distribution of Pareiorhaphis lineata in eastern Brazil. Red dots = paratypes; star = type-locality; yellow dots $=$ non-type specimens. Each symbol may represent more than one lot or locality.

Ecological notes. Pareiorhaphis lineata was captured in habitats with medium to strong water current and substrate composed of smooth bedrock, large boulders, and cobbles, in addition to small amounts of gravel and sand, usually in low depth $(<0.5 \mathrm{~m})$. No individuals were captured in sand bottomed stretches, such as beaches or pools. Rocks were sometimes covered by weeds (Podostemaceae). Rivers where specimens were collected are 0.3-4.5 m deep and 1.7-55 $\mathrm{m}$ wide, with banks covered by shrub and low trees typical of the Cerrado forest (Fig. 4). Other loricariids collected syntopically with the new species are Pareiorhaphis stephanus, Delturus brevis, Harttia garavelloi, Chauliocheilos saxatilis, Parotocinclus jequi, Parotocinclus sp., Hypostomus nigrolineatus, and Hypostomus sp., further on Astyanax aff. fasciatus, Astyanax cf. pelecus, Hemigrammus marginatus, Knodus moenkhausii, Oligosarcus macrolepis (Characidae), Characidium spp. (Crenuchidae), Trichomycterus spp. (Trichomycteridae), and juveniles of Brycon howesi (Bryconidae).
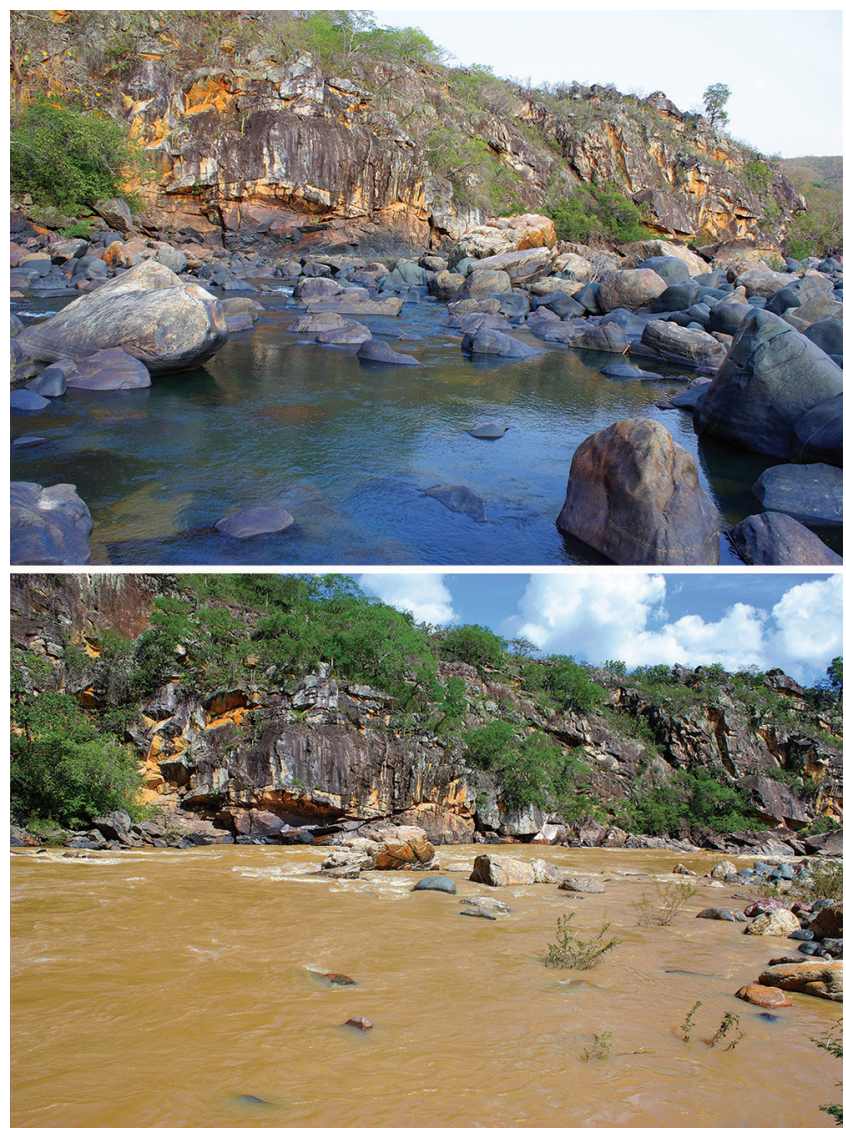

Fig. 4. Rio Itacambiruçu, where many specimens where collected, during low (above) and high (below) water seasons.

Etymology. The species name Pareiorhaphis lineata is from the Latin linea, meaning line or stripe, in reference to the dark stripe on the flank, which is distinctive of this species. An adjective.

Conservation status. Pareiorhaphis lineata is broadly distributed in the upper and middle rio Jequitinhonha basin (Fig. 3), being relatively frequent and abundant. Its Extent of Occurrence (EOO) was estimated at approximately $24,500 \mathrm{~km}^{2}$. The lower reach of the rio Itacambiruçu, the second main tributary to the rio Jequitinhonha, has been compromised by the Irapé dam reservoir. Now a series of small dams are planned for the upper and middle reaches of that river, which may substantially reduce suitable habitats for this species. Despite a variety of threats such 
as contamination by domestic sewage, species introduction (mainly Serrasalmus brandtii from the rio São Francisco), mining, damming, and deforestation, with the subsequent river siltation, were observed in portions of the area of distribution, no specific threats were detected, and Pareiorhaphis lineata should be categorized as Least Concern (LC) according to IUCN criteria (IUCN, 2016).

\section{Discussion}

Pareiorhaphis lineata was included as a member of Pareiorhaphis by sharing the several synapomorphies disclosed by Pereira, Reis (2017) for the genus, which include the remarkable morphological attributes known to occur in adult males of all congeners, as already discussed by Pereira et al. (2007) - the thickened pectoral-fin spine, fleshy lobes on the cheeks, and hypertrophied odontodes on the dorsal surface of the pectoral-fin spine and on the lateral margins of the head.

There are several similarities regarding the general color pattern of most species of Pareiorhaphis. Often, the dorsal surface of body and head is grayish to dark brown, the ventral surface is light brown to yellowish white, with the skin of the abdomen white to pale yellow. In addition, the dorsum and flanks are covered by distinct to inconspicuous dark blotches that form irregular transverse saddle-like marks, from the predorsal area to the end of the caudal peduncle. Of the 25 species of Pareiorhaphis only four diverge from that general color pattern: P. stomias, with the dorsal surface of the head and dorsum covered by many small, distinct black dots, more concentrated on the head (Pereira, Reis, 2002); P. proskynita, which has a singular color pattern among all species of Pareiorhaphis, with conspicuous dark brown blotches irregularly scattered over a yellowish tan background on the head, dorsum, and flanks (Pereira, Britto, 2012); P. vetula, with irregular and inconspicuous scattered dark brown blotches not forming saddles on the head, dorsum, or flanks (Pereira et al., 2016); and P. lineata, which is diagnosed from all remaining congeners by a putative autapomorphic feature related to the color pattern that is so far unknown among other Pareiorhaphis, a welldefined, dark brown stripe on the median series of lateral plates that extends along the flank from the posterior margin of the compound pterotic to the caudal-fin base, over a pale yellow or light brown background, further on the absence of saddle-like marks on the dorsum.

Pareiorhaphis stephanus is the single other neoplecostomine known to occur in the rio Jequitinhonha basin (Oliveira, Oyakawa, 1999), where they occur sympatrically and syntopically. The two species share some morphological traits, including a ventral caudalfin lobe that is longer than the dorsal lobe, hypertrophied odontodes that are distributed along the entire margin of the head, and aspects of the color pattern. Despite possessing morphological traits similar to $P$. stephanus, the size of the hypertrophied odontodes of $P$. lineata differs significantly.
Adult males of $P$. lineata have the largest hypertrophied odontodes on the head and pectoral-fin spine that are always shorter than one orbital diameter, while larger hypertrophied odontodes are always longer than one orbital diameter in $P$. stephanus (Fig. 5). In addition, adult males of $P$. lineata have a rounded pectoral fin-spine in cross-section and the greatest body width is located at the posterior portion of cheek, while in P. stephanus, the pectoral-fin spine is dorsoventrally flattened and the greatest body width is at the lateral margin of the cleithrum (Figs. 5 and 6). Regarding to color pattern, $P$. lineata possesses the well-defined, dark brown stripe on the median series of lateral plates that extends along the flanks, and has no saddle-like marks on the dorsum (Figs.1, 2, 6). By contrast, P. stephanus has dark brown blotches forming the typical saddle-like marks of many Pareiorhaphis species that are sometimes laterally united to form a diffuse and inconspicuous stripe on the flank (Figs. 5, 6). Regarding immature males, females, and juveniles, which are more frequently collected, the new species can be easily distinguished by the color pattern, by the head being wider than the cleithrum, by the smaller eye diameter (12.7-16.2\% vs. 18.1-20.1\% HL), and by the larger snout (60.8-66.5\% vs. 55.5-60.8\% HL).

The particular color pattern of a longitudinal stripe observed in Pareiorhaphis lineata is shared with Euryochus thysanos, an unrelated neoplecostomine that inhabits the contiguous river basins of the rio Doce, rio Mucuri, rio São Mateus, and small coastal drainages in eastern Brazil. Although the color pattern is superficially similar in the two species, E. thysanos is easily distinguished from $P$. lineata by lacking the attributes found in adult males of Pareiorhaphis, such as odontodes along the head margins and broad pectoral-fin spine, and was also shown to be not closely related to Pareiorhaphis (Pereira, Reis, 2017).

Comparative material examined. Pareiorhaphis stephanus. Brazil: Minas Gerais: Rio Jequitinhonha basin: LIRP 4562, 8, 43.0$79.8 \mathrm{~mm}$ SL. LIRP 4127, 6, 25.6-46.3 mm SL + $1 \mathrm{c \& s}, 55.1 \mathrm{~mm} \mathrm{SL}$. MCNIP 1696, 1 of 2, $91.8 \mathrm{~mm}$ SL, and MCP 51735, 3, 69.7-84.3 mm SL. MCNIP 0023, 12, 13.3-45.7 mm SL. MCNIP 0336, 1, 62.1 $\mathrm{mm}$ SL.

\section{Acknowledgments}

We are grateful to Carlos Lucena and Margarete Lucena for help and continued support provided at the MCP fish collection, to Bárbara Calegari for help with the map of Fig. 3 and, along with Douglas Mentges, for the photos of the holotype. We also thank Amarildo Rodrigues, Daniel Teixeira, Gabriel Mello, Gilberto Salvador, Guilherme Santos, Gustavo Rosa, Iago Penido, Ivo Prado, José Oliveira, Marina Pugedo, Naiara Sales, Pablo Lehmann, Sidinei Máximo, Tobias Barroso, and Waldir Santos for help during fieldwork. Samples conducted by FA were financed by Cemig Geração e Transmissão. RER is partially financed by CNPq (process \#306455/2014-5). 


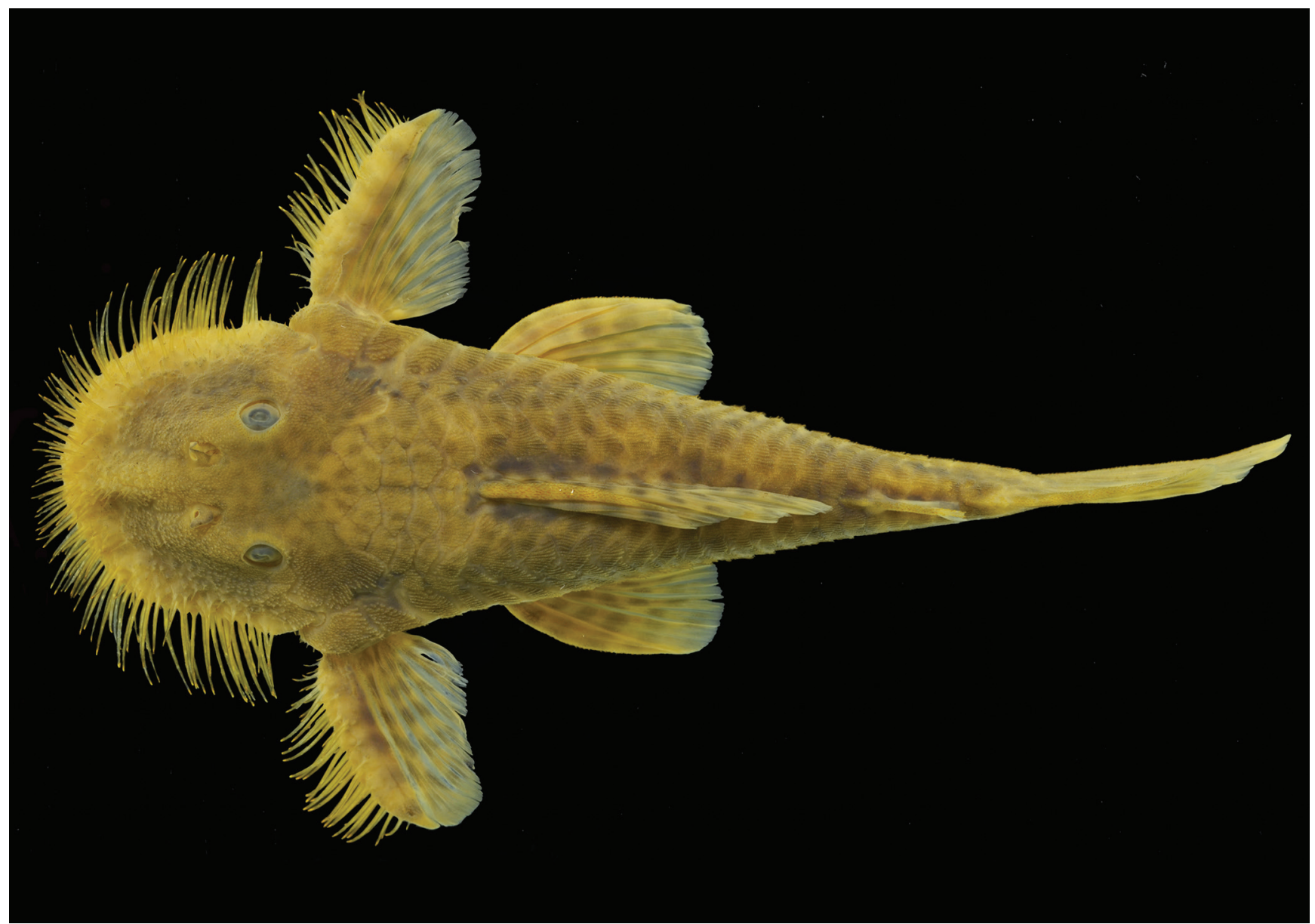

Fig. 5. Pareiorhaphis stephanus, MCNIP 1696, 91.8 mm SL, Brazil, Minas Gerais State, Cristália, rio Itacambiruçu.

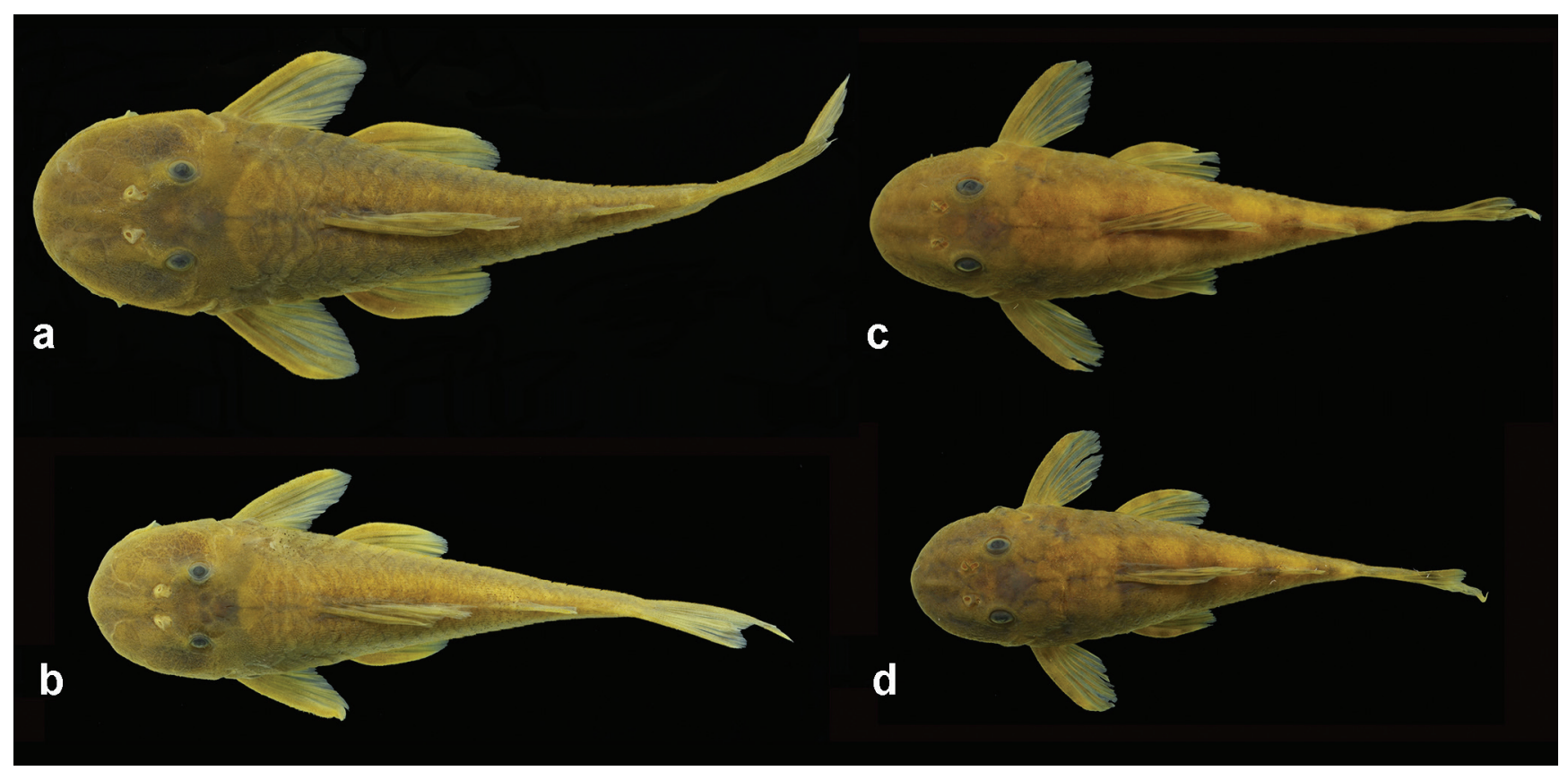

Fig. 6. General shape and color pattern of females of Pareiorhaphis lineata, a. MCP 50876, $67.6 \mathrm{~mm} \mathrm{SL,} \mathrm{and} \mathrm{b.} 56.3 \mathrm{~mm}$ SL; and P. stephanus, c. LIRP 4127, $47.4 \mathrm{~mm} \mathrm{SL}$, and d. $40.3 \mathrm{~mm} \mathrm{SL}$. 


\section{References}

Abell R, Thieme ML, Revenga C, Bryer M, Kottelat M, Bogutskaya N, Coad B, Mandrak N, Balderas SC, Bussing W, Stiassny MLJ, Skelton P, Allen GR, Unmack P, Naseka A, Ng R, Sindorf N, Robertson J, Armijo E, Higgins JV, Heibel TJ, Wikramanayake E, Olson D, López HL, Reis RE, Lundberg JG, Sabaj-Pérez HM, Petry P. Freshwater ecoregions of the world: a new map of biogeographic units for freshwater biodiversity conservation. Bioscience. 2008; 58(5):403-14.

Camelier P, Zanata AM. Biogeography of freshwater fishes from the northeastern Mata Atlântica freshwater ecoregion: distribution, endemism, and area relationships. Neotrop Ichthyol. 2014; 12(4):683-98.

International Union for Conservation of Nature (IUCN). Standards and Petitions Subcommittee. Guidelines for Using the IUCN Red List Categories and Criteria. Version 12 [Internet]. 2016 [updated $2016 \mathrm{Feb}$. Available from: http://www.iucnredlist. org/documents/RedListGuidelines.pdf

Oliveira JC, Oyakawa OT. Two new species of Hemipsilichthys (Teleostei: Loricariidae) from Serra do Espinhaço, Minas Gerais, Brazil. Ichthyol Explor Freshw. 1999; 10(1):73-80.

Pereira EHL, Britto MR. A new distinctively colored catfish of the genus Pareiorhaphis (Siluriformes: Loricariidae) from the rio Piracicaba, upper rio Doce basin, Brazil. Copeia, 2012; 2012(3):519-26.

Pereira EHL, Lehmann P, Reis RE. A new species of the neoplecostomine catfish Pareiorhaphis (Siluriformes: Loricariidae) from the coastal basins of Espírito Santo, eastern Brazil. Neotrop Ichthyol. 2012; 10(3):539-46.

Pereira EHL, Lehmann P, Reis RE. Pareiorhaphis vetula, a new armored catfish from the headwaters of the rio Doce basin, Brazil (Siluriformes: Loricariidae). Zootaxa. 2016; 4144(3):443-50.

Pereira EHL, Lehmann P, Schvanbach LJ, Reis RE. A new species of Pareiorhaphis (Siluriformes: Loricariidae) from the headwaters of the arroio Garapiá, coastal drainage of Rio Grande do Sul state, Brazil. Zootaxa. 2015; 4034(3):556-64.
Pereira EHL, Reis RE. Revision of the loricariid genera Hemipsilichthys and Isbrueckerichthys (Teleostei: Siluriformes), with descriptions of five new species of Hemipsilichthys. Ichthyol Explor Freshw. 2002; 13(2):97-146.

Pereira EHL, Reis RE. Morphology-based phylogeny of the suckermouth armored catfishes, with emphasis on the Neoplecostominae (Teleostei: Siluriformes: Loricariidae). Zootaxa. 2017; 4264(1):1-104.

Pereira EHL, Vieira F, Reis RE. A new species of sexually dimorphic Pareiorhaphis Miranda Ribeiro, 1918 (Siluriformes: Loricariidae) from the rio Doce basin, Brazil. Neotrop Ichthyol. 2007; 5(4):443-48.

Pereira EHL, Vieira F, Reis RE. Pareiorhaphis scutula, a new species of neoplecostomine catfish (Siluriformes: Loricariidae) from the upper rio Doce basin, Southeastern Brazil. Neotrop Ichthyol. 2010; 8(1):33-38.

Pereira EHL, Zanata AM. A new species of the armored catfish genus Pareiorhaphis Miranda Ribeiro (Siluriformes: Loricariidae) from the rio Paraguaçu, Bahia state, northeastern Brazil. Neotrop Ichthyol. 2014; 12(1):35-42.

Pugedo ML, Andrade Neto FR, Pessali TC, Birindelli JLO, Carvalho DC. Integrative taxonomy supports new candidate fish species in a poorly studied neotropical region: the Jequitinhonha River Basin. Genetica. 2016; 144(3):341-49.

Schaefer SA. The neotropical cascudinhos: systematics and biogeography of the Otocinclus catfishes (Siluriformes: Loricariidae). Proc Acad Nat Sci Philadelphia. 1997; 148:1-120

Taylor WR, Van Dyke GC. Revised procedures for staining and clearing small fishes and other vertebrates for bone and cartilage study. Cybium. 1985; 9(2):107-19.

Submitted June 19, 2017 Accepted August 1, 2017 by Marcelo Britto 